\title{
Lexical Transformations in the Translations of the Modern Tatar Literature into the Turkish Language
}

\author{
El'mira K. Khabibullina $^{1}$ \& Al'fiya Sh. Yusupova ${ }^{1}$ \\ ${ }^{1}$ Kazan (Volga Region) Federal University, Kazan, Russia \\ Correspondence: El'mira K. Khabibullina, 420008, Kazan, Kremlyovskaya Street 18, Russia. E-mail: \\ minabova@mail.com
}

Received: June 2, 2015 Accepted: June 15, 2015 Online Published: June 29, 2015

doi:10.5539/jsd.v8n5p164

URL: http://dx.doi.org/10.5539/jsd.v8n5p164

\begin{abstract}
The relevance of this article is caused by the versatile interest to the problem of transformation in the process of translation, which usually comes as a tradition in the theory and practice of translation. However, most of the researches are devoted to the process of translation from English into Russian and vice versa. The problem of translation from Tatar into Turkish is virtually unexplored today. Therefore, this article is concentrated at identifying and studying the types and characteristics of lexical transformations based on the translation samples of the Tatar literature. The leading approach to the problem is a systematic one, which includes the study of theoretical aspects of translation transformations reflected in the works of domestic and foreign researchers. It also assumes analysis of lexical transformations identified in under study translations, based on the theoretical framework mentioned above. The article reveals that the most common types of lexical transformations are transcription, transliteration and tracing. It was also found out that the techniques considered above are mostly used when there are no equivalents of a phenomenon or object in a target language, that is in Turkish. Thus, the translator tries to maintain the originality of the imagery and content of the work. Materials of the article can be useful in further studies: comparative, translation theory, use of lexical transformations in the practice of translation.
\end{abstract}

Keywords: lexical transformations, literary translation, tracing, transcription, transliteration, the Turkish language

\section{Introduction}

\subsection{The Relevance of the Problem}

Literary works is the jewel in the treasury of the literary heritage of any nation. It is impossible to stay indifferent when we speak about the global literary wealth. Even from an early age a person faces the samples of native and foreign literature. However, not everyone thinks that we might not have the opportunity to get acquainted with all the masterpieces of a world literature, presented by great writers and thinkers. Not everyone is given the idea that most of those works, that have already been read or are to be read, were written by authors who speak different languages.

Of course, it does not mean that for reading the foreign literature we have to know this or that foreign language, which the writing presented at. Today everyone can easily get acquainted with the literary heritage of practically all the countries and peoples, the epics of the ancient peoples of the world, philosophical treatises and works by contemporary artists, regardless of the language in which they are presented. Possibility of a general access to the products of multifaceted literary language occurred owing to the writers-translators, who are the real masters of literary translation. (Komissarov, 1990).

The translation of fiction is important enough, which in its turn lay on the writers and translators enormous responsibility, requiring their attention and concentration. They were assigned to the mission of broadcasting ideas from different countries and different cultures to those who are not able to get acquainted with the literary pearls in original. (Kazakov, 2001)

We also should remember that the translation of the fiction is significantly different from other varieties of translation. While translating a fiction the translator cannot and should not use the stable formulae and semantics of words, but has to transform the atmosphere of speech and the specifics of the original text. Such a translation 
is clearly a piece of art, because we must remember that the master of literary translation achieves an aesthetic effect using such linguistic resources as rhyme, rhythm and alliteration (Komissarov, 2002).

Translation of a fiction should conform to a particular direction, initially given by the author of the work. This, in its turn, requires the translator's total immersion in the original work and thorough study of the author's presentation style. The translator should strive for accurate and colourful reflecting of the author's idea, but oughtn't to forget that his obligation is to reconstitute the writing, and not just to transform the original text. We also should remember that in fact it is mostly a creative translation which is more interesting to the translator than the translation of technical and scientific texts.

The relevance of this article is caused by the insufficient knowledge of translation transformations in the Tatar and Turkish languages. The study of approaches of defining the types of transformations in the theory of translation, the examples of translations themselves, as well as the analysis of the classifications and types of functional features of lexical transformations is the aim of our study.

\subsection{Status of a Problem}

Identifying lexical transformations and the reasons of their usage in the process of comparing of an original Tatar writings with their translations into Turkish comes as a new and prospective line of study. During the study we mainly chose the method of comparative analysis of the texts comprising monitoring, comparing, interpretation and description of the linguistic material.

Speaking about transformations, we should outline that they are divided into grammatical and lexical transformations. In our research we will mostly pay attention to the lexical transformations. Barkhudarov L.S. (1975), who made an enormous contribution to the typology development in a translation science, made a start from the fact that the transformations which happen to occur in the process of translation are those various cross-language qualitative changes which are made to achieve the translation equivalence («the adequacy of the translation») despite the discrepancies in the formal and semantic systems of the languages.

\subsection{Lexical Transformations}

As in our research we are speaking about translation transformations it is necessary to define the meaning, which is meant in the concept. Barkhudarov L.S. (1975) made a start from the fact that the transformations which happen to occur in the process of translation are those various cross-language qualitative changes which are made to achieve the translation equivalence ("the adequacy of the translation") despite the discrepancies in the formal and semantic systems of the languages.

The term "transformation" in a translation theory has a transfer function which deals with the relations between the source and target language expressions in the process of changing one expression to another. It is a sort of replacement, which in its essence is the transition or transformation. (Kazakova, 2001) Thus, the transformations described below are nothing except of a kind of cross-language lexical and stylistic means of preserving and transmitting the stylistic features of the original text while translating it into another language.

There are different points of view on the problem of presenting different types of transformations. But most of the authors agree on one point that the main types of transformations are known as grammatical and lexical transformations. In turn, these transformations are divided into subtypes.

Studying lexical transformations is also necessary to consider the reasons they appear for. We should remember that in the lexical systems of the two languages no matter what language is considered there will always be some dissensions arising from the peculiarities of the semantic structure of words, the differences in a sense proportion, the differences in vocabulary and distinctions based on the figurative meanings of the words etc. All the facts come as the reason for the lexical transformations.

It is also necessary to point out the aspect that in modern translation theory the peculiarities of translation transformations in different languages have been thoroughly learnt (English-Russian, Turkish - English and etc.). (Yücel, 2007: Rifat, 2003; Komissarov, 2002). However, the problem of translation transformations in the process of translating between the related languages, as the Turkish and Tatar, is not virtually covered. This fact underscores the relevance and originality of the research.

\section{Materials and Methods}

\subsection{Research Objectives}

In the study we determined the following objectives: to cover the peculiarities of the translation samples of Tatar prose into the Turkish language, finding out the ways and means to convey the meaning of the work without distorting it, thus altering their shape the way the reader can understand that, and, in addition to that, to explore 
the methods and strategies widely used in translations.

\subsection{Theoretical and Empirical Methods}

We used the following mutually complementary methods to test the hypothesis of the research:

- Theoretical ones which are the analysis of the theoretical literature on research; interpretation and synthesis;

- Empirical ones which include the method of linguistic observation, the comparative method and the method of componential analysis.

\subsection{Research Basis}

As the basis of the study we determined the works on translation theory and practice of the authors of our country such as Barkhudarov L.S. (1975), Komissarov V.N. (1990, 2002) and Kazakova L.S. (2001). The practical basis was formed on the story "Maturlyk" ("Beauty") by Amirkhan Eniki (Eniki, 1978) and on the novel "Gomga kon kich belən" by Ayaz Gilyazov ("Friday night") (Gilyazov, 1978). Both of these works have been translated and published by the same translator F. Kutlu. (Giylecev, 2013), (Vasiyet, 2005).

\section{Results}

\subsection{The Problem of Classification of Lexical Transformations Identified in the Process of Analysis Tatar to Turkish Translations}

The group of lexical transformations includes several varieties. We will study them on the basis of particular examples:

1. Transcription - a way of transferring an original lexical unit by recreating its shape using the letters of the target language. When the transcription happens you usually reproduce the acoustic form of a foreign word. In the translations studied the transcription is mainly used to depict the names of phenomena which are peculiar just to one people and to one side. So, the translator uses transcription to transfer lexemes naming the objects or phenomena which exist just in the Tatar language and not in Turkish.

In the sentence «...ike raion kolkhozlary bulgach, alarnyn aradashlygy chamaly gyna ide» (Gyiləgev, 1978) (due to the fact that the villages belonged to two different districts they felt the lack of communication (translation by the author)) we meet the word «farm» borrowed from the Russian language. This word is not familiar to a Turkish reader. That's why, the translator uses transcription and the translation comes as following: «kolhoza yeni yönetici geldi» (Giylecev, 2013). However, the translator in order to make the word «farm» clear to the reader gives a footnote at the end of the page which describes in detail the meaning of the original word.

The translation of the word «muncha» (bath) in the following sentence is also interesting: «...muncha urynnaryn kychytkan, ak ərem həm alabuta basty». (Gyiləgev, 1978) (nettles, wormwood and weed expanded all the space around the bath (author's translation). In the Turkish language the word «muncha» (bath) can be replaced with a lexeme «hamam». However, in fact, a Tatar bath and a Turkish bath cannot be completely equivalent. In this case, the translator has to resort to a transcription again and to give a footnote to describe the specific features of the concept. In a translation, the sentence comes as following: «... munçanın olduğu yeri isırganlar, deve dikenleri bast1 ...» (Giylecev, 2013).

2. Transliteration. Translating the geographical names and proper names the translator usually uses transliteration that is a method of transmitting the graphic form of a word. So there are some examples.

«Omma minem ochen Aksyrgak avyly, Tashlyyar elgasy tagyn da shəbrək yangyryi» (Gyiləgev, 1978). (However, hearing the phrases Aksyrgak village and river Tashlyyar is much more pleasant for me (translation by the author)). In this sentence, we meet a toponym «Aksyrgak» and a hydronym «Tashlyyar». Translator has also transliterated these lexemes into the Latin script. «Ama Aksırgak köyü, Taşlıyar Çayı benim kulağıma daha hoş geliyor» (Giylecev, 2013). We face the same phenomenon while translating proper names - the names of the heroes of the story: Gihangir Səfərgalin - Cihangir Sefergalin, Bibinur karchyk - Bibinur kadın; the name of the street Yugary Bash - Yukarı Baş, the national holiday Sabantui - Sabantoy etc.

Researching the process of transcription and transliteration it is necessary to remember the fact that the source Tatar language and the target Turkish language are related Turkic languages. So here we can have the illusion of enormous transcriptions based on the lexemes common to both languages which come as Turkic language units or borrowed ones, mostly from the Arabic and Persian languages. These lexemes sometimes have full phonetic coincidence, but sometimes we can see the phonetic shift characteristic of a particular language.

Let's refer to some of them:

- $\quad$ mərmər - mermer (granite) - full match 
- məktəp - mektep (school) - full match

- yala - yele (mane) - shift between the hard and soft vowels a - э

- $\quad$ kory - kuru (dry) - shift between the wide and narrow vowels o-y and between the labial and not labial ones ы - y

- $\quad$ bərəkətle - bereketli (grace) - shift between the wide and narrow vowels e - и

- $\quad$ keshnədelər - kişnediler (neighing) - shift between the wide and narrow vowels and е - и

- $\quad$ tufrak - toprak (earth, soil) - shift between the consonants $\phi-\Pi$

- $\quad$ mullyk - bolluk (prosperity, wealth) - shift between the consonants м - 6 and vowels y - o, b - y.

As we can see in the examples above the words common to both languages make up a large layer of vocabulary. However, there are some cases when the words common for both languages have different meanings. For example the word əylənergə (to spin) in the Tatar language has the version eğlenmek in Turkish, but stands for "to have fun, to enjoy oneself" etc.

3. Tracing. During the investigation of the original and the translated texts mentioned above we were attracted to the usage of tracing, which is known as the method of creating a new word or a set phrase copying the structure of the original lexical unit. Sometimes it is an unavoidable phenomenon in the transmission of values which are not familiar to the target reader. We are talking about semantic tracing. Thus translating the phrase "Verkhovnyi Sovet» (the Supreme Council) we can use the phrase «Yüksek Sovyet Meclisi». The same way the phrase "Vatan sugyshy» (Patriotic War) was translated into the Turkish language - «Vatan Savaşı».

Phraseological tracing is also wildly used in the translations

Tuk korsak kollary - midemizin kulları (slaves of their own well-fed stomachs - slaves of their own whims)

Kunele iomshady - gönlü yumuşadı (to grow lenient)

Avylnyp ochynda - köyün ucunda (at the edge of the village - at the end of the village).

In the process of phraseological tracing we notice the effect of the similarity of the related languages again. Supposing that there are no set expressions of the same origin in the Turkish language we can notice that the meaning of the source text is not much distorted in the translated one.

\section{Discussions}

Lexical transformations, as a kind of translation transformations are well studied in the works of Russian (Barkhudarov, 1975; Komissarov, 1990, 2002) and foreign (Rıfat, 2003; Yücel Faruk, 2007) researchers. In their papers they studied in detail the theoretical aspects of translation studies, they defined the classification of transformations, which served as the basis for the classification of lexical transformations in our study. However, recapping the material, we should emphasize that these studies focused on the transformations research taking place in the Russian-English (Anglo-Russian), and Turkish-English (Anglo-turtsekom) translations. The study of transformations, which are characteristic of the Tatar-Turkish translation, today remains unexplored. We, relying on the theoretical aspects of the researchers by the authors enumerated earlier, have attempted to carry out lexical transformations identified in the process of analysis of the fiction translated from the Tatar language into Turkish.

\section{Conclusions}

Thus, in the examples above, we have investigated the forms of lexical transformation such as transcription, transliteration and tracing. These are the most common types of translation transformations. The research reveals the fact that in the process of fiction translation from Tatar to Turkish we commonly address to the methods described when there are no equivalents of a phenomenon or object in the target language, that is Turkish. Thus, the translator tries to maintain the imagery and content originality of the work. And a frequent reference to the loan translation fits harmoniously the target text. That happens because of the intimacy of the languages considered.

This research is important for the Russian students studying the Turkish language and for the Turkish universities studying the Tatar language, for their teachers and for all those involved in translation and interested in various translation disciplines.

\section{Acknowledgments}

The work is performed according to the Russian Government Program of Competitive Growth of Kazan Federal University. 


\section{References}

Barkhudarov, L. S. (1975). Yazyk i perevod [Language and translation]. Moscow: Mezhdunarodnye otnosheniya publ., 190.

Eniki, Ә. (1978). Yulchy. Khikayalər [The wanderer. Stories]. Kazan: Tat.kit.nəshr. publ., 468.

Giylecev, A. (2013). Cuma Günü, Akşam. Ankara: Bengü Yayınları, 202.

Göktürk, A. (2000). Çeviri: Dillerin Dili. Ankara, 350.

Gyiləжеv, A. (1978). Sailanma əsərlar [Selected works]. Kazan: «Khəter» publ., 510.

Kazakova, T. A. (2001). Prakticheskie osnovy perevoda [Practical bases of translation]. Saint-Petersburg, 320.

Komissarov, V. N. (1990). Teoriya perevoda (lingvisticheskie aspekty) [Theory of translation (the linguistic aspects)]. Moscow, 253.

Komissarov, V. N. (2002). Sovremennoe perevodovedenie [The modern translation science]. Moscow, 157.

Rıfat, M. (2003). Çeviriyi Düşünenler. İstanbul. Dünya Yayıncılık.

Vasiyet.Türk Klasikleri Serisi. (2005). İzmir, 144.

Yücel, F. (2007). Tarihsel ve Kuramsal Açıdan Çeviri Edimi. Ankara: Dost Yayınevi.

\section{Copyrights}

Copyright for this article is retained by the author(s), with first publication rights granted to the journal.

This is an open-access article distributed under the terms and conditions of the Creative Commons Attribution license (http://creativecommons.org/licenses/by/3.0/). 